\title{
FUNCTIONAL COMPLICATIONS FOLLOWING BREAST CANCER THERAPY AND THE ROLE OF REHABILITATION IN RECOVERY OF FUNCTIONAL STATUS - A CASE REPORT
}

\author{
Popović-Petrović Svetlana, ${ }^{1,2}$ Kovač Aleksandra, ${ }^{1}$ Novakov Ivana, ${ }^{1}$ Tatić Milanka ${ }^{1,2}$ \\ ${ }^{1}$ Oncology Institute of Vojvodina, Sremska Kamenica, Serbia \\ ${ }^{2}$ Faculty of Medicine, University of Novi Sad, Serbia
}

Primljen/Received 23. 01. 2017. god.

Abstract: Introduction. The most common functional complications after the treatment of breast cancer are reduction of range of motion in the shoulder joint (incidence of 10 to $73 \%$ ), lymphedema of the arm (10-30\%) and nerve damage of the arm or damage of brachial plexus (1.8-4.9\%). Multiple complications rarely occur and they are usually of mild to moderate forms.

Case report. VV (woman), born in 1965 was exposed to quadrantectomy of the left breast with axillary dissection in 2003 (histopathology: ductal carcinoma; 4 removed lymph nodes, 1 of which with a secondary deposit). After the surgical intervention, the patient underwent chemotherapy (CMF protocol VI cycles) and radiation therapy (50 Gy/12 cycles). Four months after the therapy completion, lymphedema of the left arm was developed, and few months later brachial plexus injury as well. First visit to physiatrist was five years later, with a significant reduction of range of motion in the left arm and severe lymphedema (maximum difference to $7.5 \mathrm{~cm}$ ). EMNG trial indicated a moderate lesion of left median nerve and ulnar nerve and mild to moderate lesion of left radial nerve injury; DASH score was 107. After repeated physical treatments (since 2009), the last control in October 2016 showed that the functional status was significantly improved: reduction of range of motion was present in flexion and abduction only, lymphedema was reduced (maximum difference of $5.5 \mathrm{~cm}$ ); DASH score was 48 , while EMNG indicated a lesion of the median nerve and ulnar nerve in lower level, with signs of recovery.

Conclusion. The implementation of an early rehabilitation program for the patients who were surgically treated for breast cancer is necessary in order to prevent functional complications and to enable contin-
Prihvaćen/Accepted 15. 03. 2017. god.

uous monitoring of the patients, while in the case with already developed complications, physical therapy should be initiated regardless of the period in which the functional limitations occurred.

Key words: breast cancer, functional complications, physical treatment.

\section{INTRODUCTION}

Functional complications in breast cancer may occur as a consequence of therapy (surgery with or without axillary dissection, radiotherapy, chemotherapy) (1-4), absence of the early rehabilitation program and influence of natural factors (trauma, physical overload) (4-6). The most common are: reduction in range of motion in the shoulder joint of ipsilateral arm, with an estimated incidence of $10-73 \%(7,8)$, secondary lymphedema of the arm (average incidence 20-30\%) $(9,10)$, nerve damage of the arm or brachial plexus, which is reported in $1.8-4.9 \%$ of patients with breast cancer (11). Those complications are mostly individual and in most cases mild, while their persistence leads to permanent dysfunction of the ipsilateral arm $(5,6)$.

The main aim of this case report is to show the effect of rehabilitation interventions in improving the functional state in conditions of chronic and permanent damage caused by the treatment of breast cancer.

\section{CASE REPORT}

VV (woman), born in 1965 underwent surgery on 1st Ferbuary 2003. Quadrantectomia mammae lateris sinistri (histopathological findings: Carcinoma ductale infiltrativum; HG2; tumor size $30 \times 26 \times 18 \mathrm{~mm}$; localization: upper lateral quadrant; 4 removed lymph nodes, 1 of which includes a secondary deposit. After the 
surgical intervention, the patient underwent therapy prescribed by the breast cancer multidisciplinary team: CMF chemotherapy, VI cycles (March 2003). Radiotherapy conducted during May and June, 2003: TD 50 $\mathrm{Gy} / 12$ fractions on the second day (area of the rest of the breast tissue, axilla and supraclavicular region).

Swelling of the left hand appeared four months after the completion of radiotherapy. The patient did not receive a treatment of lymphedema. In May 2004, she began to feel numbness of the left hand and the inability to raise her left arm. A few weeks later, she complained of pain in her left hand, with the inability to perform daily activities with her left hand.

During the first visit to the Oncology Institute of Vojvodina (IOV), Department of Rehabilitation, on 25 May 2009, the patient complained of pain (Visual Analogue Scale - VAS = 5) and a feel of ,weight" of the left arm.

Reports: Disease free according to medical oncologist (12 May 2009). Laboratory findings and breast tumor marker (CA 15-3) were within normal ranges. Abdominal ultrasound examination: nothing abnormal detected. Computed tomography of the chest (17 January 2008): postradiation fibrotic changes apically and in the upper lobe of the lungs leftward, with no secondary deposits. The old fractures of III and IV ribs with marginal sclerosis and the development of pseudoarthrosis were observed. Those fractures were a consequence of severe postradiation osteoporosis, with no signs of bone dissemination of the disease.

Objective findings: pronounced, fibrotic, reddish-livid colour changes in skin of the left hemithorax, axillary and supraclavicular region (Figure 1). Mild flexion contracture in the left elbow joint and radial deviation in the left radiocarpal (RC) joint. Edema of the left forearm as a whole (without hand) and lower $2 / 3$ of the upper arm with unchanged skin colour.

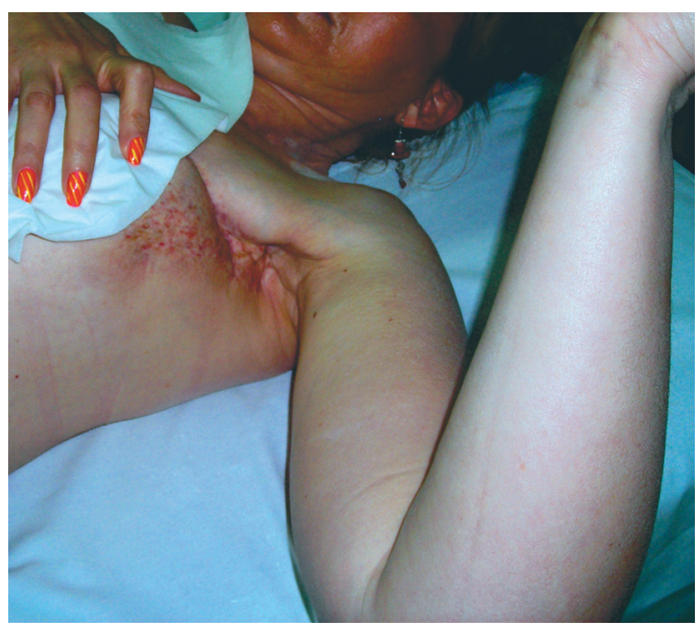

Figure 1. Postradiation fibrotic changes in skin of the chest and axillary region

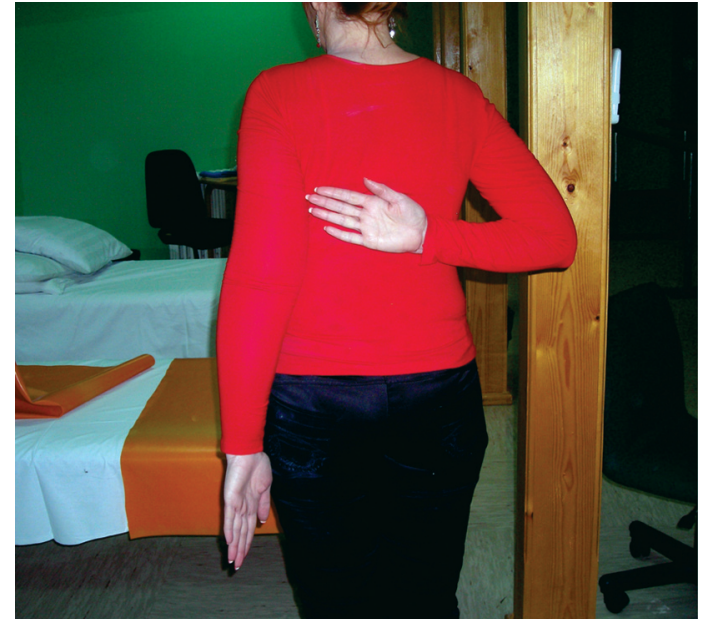

Figure 2. The internal rotation in both shoulder joints - before starting treatment

Palpatory: edema of firmer consistency, with palpatory zone of fibrosis (junction of the upper and middle thirds of the upper arm). Range of motion in the shoulder joint: abduction (abd) $80^{\circ}$; flexion (fl) $80^{\circ}$, extension (ext) $30^{\circ}$, external rotation (SR) $10^{\circ}$, internal rotation (UR) $0^{\circ}$ (Figure 2 ). The range of the extremities (edematous/contralateral hand difference): over the metacarpophalangeal joint (MCP) - there is no difference; over the RC joint - difference is $1 \mathrm{~cm} ; 10 \mathrm{~cm}$ below the olecranon - difference is $7.5 \mathrm{~cm}$; over the olecranon difference is $6 \mathrm{~cm}$; $10-15 \mathrm{~cm}$ above the olecranon - difference is $7.5 \mathrm{~cm}$. Manual muscle testing (MMT): except the flexor carpi ulnaris muscle (2+), scores for all the other muscles of the left shoulder-scapular area and segments of the left arm range from 3- to 3+. The Disabilities of the Arm, Shoulder and Hand score (DASH) is 107. Electromyoneurography (EMNG): chronic lesions of the left median and ulnar nerve to moderate degree and left radial nerve from mild to moderate degree.

Physical therapy was performed at the Department of rehabilitation of IOV since 2009, 2-3 times per year, 10-15 treatments each time. The therapy included kinesiotherapy, manual lymphatic drainage and education (risk factors, protective factors and kinesiotherapy at home).

The last check-up with a physiatrist was in October 2016. Patient subjectively rated herself as mostly pain-free. Periodically, "when she works too much", there is a pain of mild intensity (Visual Analogue Scale - VAS = 1-2) and the inability to raise her left arm above her shoulder. Functional status: range of motion in the left shoulder joint: abd $90^{\circ}$; fl $110^{\circ}$; ext $30^{\circ}$; SR $40^{\circ}$; UR $80^{\circ}$ (Figure 3 ). The scope of the extremities (edematous/contralateral arm difference): over MCP 1 $\mathrm{cm}$; over RC joint $1 \mathrm{~cm} ; 10 \mathrm{~cm}$ below the olecranon 5.5 $\mathrm{cm}$; over the olecranon $5.5 \mathrm{~cm} ; 10-15 \mathrm{~cm}$ above the olecranon, range difference is $4.5 \mathrm{~cm}$. MMT: scores 4 


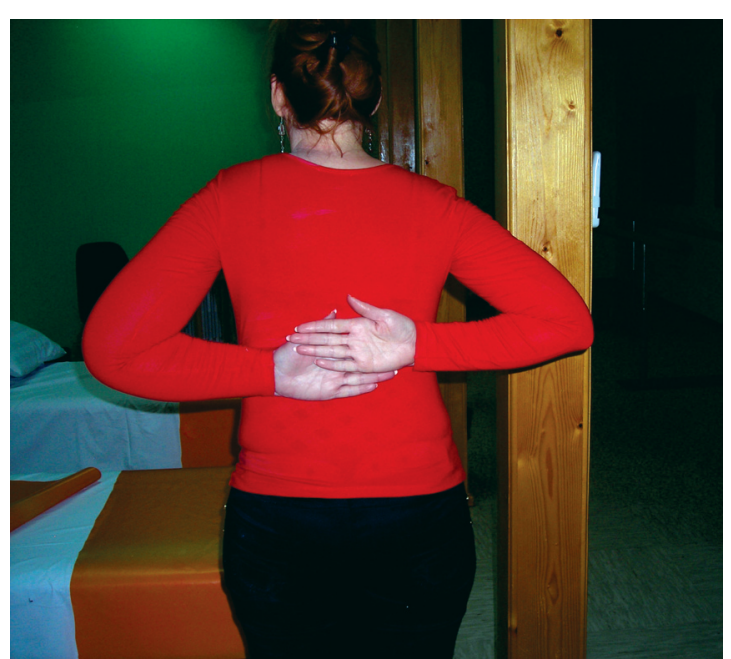

Figure 3. The internal rotation in both shoulder joints - the last check-up

for all muscles of the left arm's segments and shoulder-scapular area, except for the muscles of the left thumb (score 4-). DASH score was 48. EMNG - control: lesion of the left median and ulnar nerve is now quite mild - improvement, reporting signs of recovery.

\section{DISCUSSION}

This case is interesting for several reasons:

1. The literature has shown incidences of separate functional post-therapeutic complications in breast cancer in the form of contractures in the segments of the ipsilateral arm $(7,8)$, lymphedema of the arm $(9$, 10) and brachial plexus lesions (11). We did not find any representation of multiple functional post-therapeutic complications in existing literature, as we have described it in our case.

2. In addition, the findings of $\mathrm{CT}$ of the thorax which describes expressed postradiation sequel to the lung parenchyma, with the consequent osteoporosis and fracture of III and IV ribs and formation of pseudoarthrosis, is an additional adverse factor, which prevents further increase of range of motion in the left shoulder joint. Maximum increase of range of motion abd to $90^{\circ}$ and fl to $110^{\circ}$, below the threshold of pain is safe in relation to the possibility of re-fracture of the ribs.

3. Lack of early rehabilitation - the patient was not operated in IOV and since 1996, IOV has implemented the program of early rehabilitation of patients surgically treated for breast cancer, according to a constructed algorithm of early rehabilitation (12), therefore multiple functional complications and individual complications of severe degree have not been reported.
4. Lack of rehabilitation programs (for unknown reasons) immediately after the occurrence of lymphedema or later, after the development of plexopathy and consequently significantly reduced abilities to perform daily activities, greatly reduced the possibility of full restitution of resulting functional limitations.

5 . Inclusion in a rehabilitation program 6 years after completion of therapy, and 5 years after developed post-therapeutic complications, and significant functional recovery are confirmation that the rehabilitation interventions should be carried out regardless of the temporal distance from the occurrence of functional complications.

6. Finally, the patient's subjective perception of quality of life has improved significantly, she carries out daily activities, which is best illustrated by the words of the patient "now I can put on my bra and belt by myself."

\section{CONCLUSION}

The introduction of an early rehabilitation program in patients who underwent breast cancer surgery, continuous monitoring and rehabilitation program immediately after the diagnosis of functional complications is necessary for good quality of life of patients with breast cancer, while in the case with already developed complications, physical therapy should be initiated regardless of the period in which the functional limitations occured.

\section{Abbreviations}

DASH score - The Disabilities of the Arm, Shoulder and Hand score

CMF - Cyclophosphamide, Methotrexate, Fluorouracil

$$
\begin{aligned}
& \text { EMNG - Electromyoneurography } \\
& \text { IOV - Oncology Institute of Vojvodina } \\
& \text { MMT - Manual muscle testing } \\
& \text { MCP - Metacarpophalangeal joint } \\
& \text { RC - Radiocarpal joint } \\
& \text { VAS - Visual Analogue Scale }
\end{aligned}
$$

\section{Conflict of interest}

The authors declare that there is no conflict of interest.

\section{Licensing}

This work is licensed under a Creative Commons Attribution 4.0 International (CC BY 4.0) Licence. 


\title{
Sažetak
}

\section{POSTTERAPIJSKE KOMPLIKACIJE KOD KARCINOMA DOJKE I ULOGA REHABILITACIJE U FUNKCIONALNOM OPORAVKU — PRIKAZ SLUČAJA}

\author{
Popović-Petrović Svetlana, ${ }^{1,2}$ Kovač Aleksandra, ${ }^{1}$ Novakov Ivana, ${ }^{1}$ Tatić Milanka ${ }^{1,2}$ \\ ${ }^{1}$ Institut za onkologiju Vojvodine, Sremska Kamenica, Srbija \\ ${ }^{2}$ Medicinski fakultet Univerziteta u Novom Sadu, Novi Sad, Srbija
}

Uvod. Najčešće funkcionalne komplikacije nakon terapije karcinoma dojke su kontraktura u ramenom zglobu (incidencija 10\%-73\%), limfedem ruke (10-30\%) i oštećenje nerava ruke ili brahijalnog pleksusa (1,8-4,9\%). Retko se javljaju udružene komplikacije i uglavnom su blažeg ili umerenog oblika.

Prikaz slučaja. V. V. 1965, kvadrantektomija leve dojke sa disekcijom aksile rađena 2003. godine (patohistološki nalaz: duktalni karcinom; 4 izvađene limfne žlezde od kojih je 1 sa sekundarnim depozitom). Potom je primila hemioterapiju (protokol CMF VI ciklusa) i zračnu terapiju (50 Gy/12 ciklusa). Četitri meseca nakon završene terapije, razvija se limfedem leve ruke, a nekoliko meseci kasnije i oštećenje brahijalnog pleksusa. Prvi put se javlja kod fizijatra nakon pet godina, sa značajnom redukcijom obima pokreta u segmentima leve ruke, izraženim limfedemom (najveća razlika do 7,5 cm). EMNG

\section{REFERENCES}

1. Armer JM, Fu MR, Wainstock JM, Zagar E, Jacobs LK. Lymphedema following breast cancer treatment, including sentinel lymph node biopsy. Lymphology. 2004; 37(2): 73-91.

2. Stubblefield DM. Radiation fibrosis syndrome: neuromuscular and musculosceletal complications in cancer survivors. PM R. 2011; 3(11): 1041-54.

3. Hojan K, Milecki P. Opportunities for rehabilitation of patients with radiation fibrosis syndrome. Rep Pract Oncol Radiother. 2013; 19(1): 1-6.

4. Hack FT, Kwan BW, Tomas-Macklean LR, Towers A, Miedema B, Tilley A, et al. Predictors of arm morbiity following breast cancer surgery. Psychooncology. 2010; 19(11): 1205-12.

5. Cinar N, Seckin U, Keskin D, Bodur H, Bozkurt B, Cengiz $\mathrm{O}$. The effectiveness of early rehabilitation in patients with modified radical mastectomy. Cancer Nurs. 2008; 31(2): 160-5.

6. Chan DN, So KW. Developing an evidence-based exercise guideline on improving shoulder motion and lessening the severity of lymphedema for breast cancer patients after axillary lymph-node dissection. Clin Oncol Cancer Res. 2010; 7(3): 169-74.

\section{Correspondence to / Autor za korespondenciju}

Popović-Petrović Svetlana

Oncology Institute of Vojvodina

21204 Sremska Kamenica, Put dr Goldmana 4

E mail: petrovic.svetlana@onk.ns.ac.rs

Phone: + 381214805489

Fax: + 381216613741 ispitivanje je ukazalo na umerenu leziju levog n.medianus-a i levog n.ulnaris-a i lako do umerenu leziju levog n.radialis-a; DASH skor je bio 107. Nakon ponavljanih fizikalnih tretmana (od 2009), na poslednjoj kontroli oktobra 2016. funkcionalni status je značajno poboljšan: redukcija pokreta samo u fleksiji i abdukciji, limfedem redukovan (najveća razlika 5,5 cm); DASH skor je 48, a EMNG ukazuje na leziju n.medianus sinistri i n.ulnaris sinistri lakšeg stepena, uz znake oporavka.

Zaključak. Neophodno je uvođenje programa rane rehabilitacije kod operisanih od karcinoma dojke radi prevencije funkcionalnih komplikacija, kontinuirano praćenje pacijenata, a kod razvijenih komplikacija, fizikalni tretman započeti bez obzira na vremenski period od nastanka funkcionalnih ograničenja.

Ključne reči: karcinom dojke, funkcionalne komplikacije, fizikalni tretman.

7. Chun MS, Moon SM, Lee HJ, Lee EH, Song YS, Chung YS, et al. Arm morbidity after breast cancer treatments and analysis of related factors. J Korean Soc Ther Radiol Oncol. 2005; 23(1): 32-42.

8. Thomas-Macklaen RL, Hack T, Kwan W, Towers A, Miedema B, Tilley A. Arm morbidity and disability after breast cancer: new directions for care. Oncol Nurs Forum. 2008; 35(1): 65-71.

9. Deo SVS, Ray S, Rath GK, Shukla NK, Kar M, Asthana $S$, et al. Prevalence and risk factors for development of lymphedema following breast cancer treatment. Indian J Cancer. 2004; 41(1): 8-12.

10. Popovic-Petrovic S, Nedeljkovic M, Popovic L, Petrovic $\mathrm{V}$. Secondary lymphedema of the arm in breast carcinoma at the Încology Institute of Vojvodina: 2001- 2006. HealthMED 2011; 5(6): 1719-24.

11. Topkan E, Onal C, Yavuz N, Yavuz A. Pathophysiology and treatment of radiation induced brachial plexopathy. Int J Hematol Oncol. 2008; 3(18): 180-5.

12. Popović-Petrović S, Tomić S, Nedeljković M, Popović L, Matovina G. Early rehabilitation in patients operated for breast carcinoma. Vojnosanit Pregl. 2013; 70(4): 407-10. 